\title{
MOTIVASI MAHASISWA BERORGANISASI DI KAMPUS
}

\author{
Niken Cahyorinartri \\ Fakultas Psikologi, Universitas Jendral Ahmad Yani \\ niken.cahyorinartri@lecture.unjani.ac.id
}

\begin{abstract}
The aim of this study is to describe the student's motivation in participating in student organizations at Universitas Jenderal Achmad Yani. This study uses self-determination theory to explain the motivation of students to involve in student organizations. Self-determination theory explained that human motivations were important sources in the development of personality and self-regulation. The motivation involved the reasons and the purposes in performing an action. Motivation moves from extrinsic motivations to intrinsic motivations. The method of this study was quantitative descriptive research. Participant of this research were college students who participating in students organizations. The result showed that most of the students participated in student organizations had integration extrinsic motivation. Students involved in the student organizations because they interested and it gived them some benefits. Draw the benefits in students organizations become the majority reasons of the students in participating in the student organizations.
\end{abstract}

Keywords: motivation, organization, self determination theory

\begin{abstract}
Abstrak
Tujuan dari penelitian ini untuk mengetahui gambaran motivasi mahasiswa menjadi anggota organisasi kemahasiswaan di Universitas Jenderal Achmad Yani. Penelitian ini menggunakan self determination theory untuk menjelaskan motivasi mahasiswa terlibat dalam organisasi mahasiswa. Self determination theory merupakan pendekatan yang memandang motivasi manusia sebagai sumber yang penting dalam perkembangan kepribadian dan regulasi diri. Tipe motivasi dibedakan berdasarkan alasan dan tujuan yang diberikan dalam melakukan suatu tindakan. Tipe motivasi bergerak dari motivasi eksterinsik hingga motivasi intrinsik. Metode penelitian yang digunakan adalah penelitian deskriptif kuantitatif. Partisipan penelitian adalah mahasiswa yang aktif mengikuti organisasi kemahasiswaan baik struktural maupun peminatan. Hasil penelitian menunjukkan bahwa sebagian besar mahasiswa mengikuti organisasi kemahasiswaan berada pada motivasi ekstrinsik dengan tipe integrasi. Mahasiwa mengikuti organisasi karena mereka memiliki minat serta merasa bahwa kegiatan organisasi bermanfaat bagi diri mereka. Kesadaran terhadap keuntungan yang didapatkan ketika mengikuti organisasi menjadi hal yang mendorong mahasiswa untuk menampilkan usaha maksimal ketika mengikuti organisasi kemahasiswaan baik struktural maupun ekstrakulikuler.
\end{abstract}

Kata kunci: motivasi, organisasi, teori determinasi diri 


\section{PENDAHULUAN}

Tugas seorang mahasiswa di perguruan tinggi tidak hanya semata-mata untuk belajar. Terdapat banyak keterampilan yang perlu diraihnya hingga mereka siap menghadapi tuntutan di dunia kerja. Salah satu keterampilan yang diharapkan dimiliki mahasiswa adalah perilaku yang terorganisir. Perilaku terorganisir tidak hanya membantu mahasiswa untuk berada pada jalurnya, tetapi juga membantu mahasiswa untuk menyiapkan diri menghadapi dunia kerja (Ray, 2016).

Undang-undang nomor 20 tahun 2003 pun secara gamblang pada pasal 4 ayat 5 menyampaikan bahwa prinsip pendidikan Indonesia diselenggarakan dengan memberikan teladan, membangun kemauan, dan mengembangkan kreativitas peserta didik dalam proses pembelajaran. Selain UU nomor 20 tahun 2003, Pemerintah pun mengeluarkan Undangundang nomor 12 tahun 2012 mengenai Pendidikan Tinggi. Pada bagian "menimbang" disampaikan bahwa

"untuk meningkatkan daya saing bangsa dalam menghadapi globalisasi di segala bidang, diperlukan pendidikan tinggi yang mampu mengembangkan ilmu pengetahuan dan teknologi serta menghasilkan intelektual, ilmuwan, dan/atau profesional yang berbudaya dan kreatif, toleran, demokratis, berkarakter tangguh, serta berani membela kebenaran untuk kepentingan bangsa."

Perguruan Tinggi, sebagai salah satu lembaga yang berperan dalam mengembangkan SDM tentunya harus lebih banyak berperan dalam mengantisipasi hal tersebut di atas. Berdasarkan undang-undang nomor 12 tahun 2012 tentang Pendidikan Tinggi pasal 5 a dan b, disebutkan bahwa pendidikan tinggi bertujuan a. Berkembangnya potensi Mahasiswa agar menjadi manusia yang beriman dan bertakwa kepada Tuhan Yang Maha Esa dan berakhlak mulia, sehat, berilmu, cakap, kreatif, mandiri, terampil, kompeten dan berbudaya untuk kepentingan bangsa; b. Dihasilkannya lulusan yang menguasai cabang Ilmu Pengetahuan dan/atau Teknologi untuk memenuhi kepentingan nasional dan peningkatan daya saing.

Pihak universitas sebenarnya telah menyediakan sarana untuk mahasiswa agar terbiasa untuk bekerja secara terorganisir yaitu organisasi kemahasiswaan. Sesuai dengan yang tertera pada pasal 5 Kepmendikbud No. 155/U/1998 bahwa fungsi organisasi kemahasiswaan merupakan sarana pengembangan akademik dan pengembangan diri. Bahkan lebih lanjut diharapkan sebagai wadah mahasiswa untuk melakukan usaha perbaikan bangsa. Organisasi kemahasiswaaan diharapkan dapat menjadi sarana bagi mahasiswa untuk mengembangkan perilaku sosial dan berkelompok. Dengan bergabung aktif dalam "organisasi kemahasiswaan" yang bersifat intra ataupun ekstra kampus berefek kepada perubahan yang signifikan 
terhadap wawasan, cara berpikir, pengetahuan dan ilmu-ilmu sosialisasi, kepemimpinan serta manajemen kepemimpinan yang notebene tidak diajarkan dalam kurikulum normatif perguruan tinggi namun, dalam berorganisasilah dapat diraih dengan memanfaatkan statusnya sebagai mahasiswa.

Sementara itu, Undang-undang nomor 12 tahun 2012 tentang Pendidikan Tinggi pasal 14 menyatakan bahwa:

1. Mahasiswa mengembangkan bakat, minat, dan kemampuan dirinya melalui kegiatan kokurikuler dan ekstrakurikuler sebagai bagian dari proses Pendidikan.

2. Kegiatan kokurikuler dan ekstrakurikuler sebagaimana dimaksud pada ayat (1) dapat dilaksanakan melalui organisasi kemahasiswaan.

3. Ketentuan lain mengenai kegiatan kokurikuler dan ekstrakurikuler sebagaimana dimaksud pada ayat (1) diatur dalam Statuta Perguruan Tinggi.

Selanjutnya pada pasal 77 disampaikan bahwa fungsi Organisasi Kemahasiswaan adalah

1. Mewadahi kegiatan Mahasiswa dalam mengembangkan bakat, minat, dan potensi Mahasiswa;

2. Mengembangkan kreativitas, kepekaan, daya kritis, keberanian, dan kepemimpinan, serta rasa kebangsaan;

3. Memenuhi kepentingan dan kesejahteraan Mahasiswa; dan

4. Mengembangkan tanggung jawab sosial melalui kegiatan Pengabdian kepada Masyarakat.

Sementara, berdasarkan Kepmendikbud 155-u-1998 salah salah satu fungsi Organisasi Kemahasiswaan adalah (5) pengembangan pelatihan keterampilan organisasi, manajemen dan kepemimpinan mahasiswa.

Pemerintah secara tegas mengakui bahwa kegiatan kokurikuler dan ekstrakurikuler melalui organisasi kemahasiswaan merupakan bagian dari proses pendidikan yang diharapkan dapat mengembangkan kemampuan mahasiswa khususnya softskills. Namun sangat disayangkan pada Undang-undang no 12 tahun 2012 tersebut tidak dijelaskan secara rinci bagaimana standar pengelolaan organisasi kemahasiswaan harus dilakukan dan lebih menyerahkan standar pengelolaan tersebut pada statuta di masing-masing perguruan tinggi. Penyerahan pengelolaan organisasi kemahasiswaan kepada masingmasing perguruan tinggi berdampak pada beragamnya aturan yang berkaitan dengan organisasi kemahasiswaan. Bahkan seringkali pengelolaan dan aktivitas kemahasiswaan 
diserahkan sepenuhnya kepada pengurus yang pada saat itu sedang menjabat sedangkan lembaga hanya berperan sebagai fungsi kontrol saja.

Pada kenyataannya kesadaran mahasiswa dalam berorganisasi cenderung semakin berkurang. Mahasiswa lebih memilih untuk menganggap bahwa Universitas sekedar sebagi tempat untuk menuntut ilmu. Padahal Campbell (Jex, 2002) menjelaskan bahwa melalui berorganisasi, mahasiswa dilatih untuk menunjukkan usaha dan komitmen mereka terhadap tugas yang dihadapi. Murphy (Jex, 2002) menambahkan bahwa dengan berorganisasi, mahasiswa diajak untuk membiasakan diri untuk menampilkan perilaku yang berorientasi pada tugas yang dihadapi. Mahasiswa juga dibiasakan untuk berorientasi secara interpersonal.

Berdasarkan self-determination theory perilaku manusia dilatar belakangi suatu kontinum penentuan diri (Ryan \& Deci, 2000a). Kontinum ini berkisar dari tidak termotivasi hingga motivasi intrinsik. Sepanjang kontinum ini terdapat empat jenis motivasi ekstrinsik dari yang paling eksternal hingga diatur secara terregulasi. Empat jenis motivasi ekstrinsik ini meliputi regulasi eksternal, introyeksi, identifikasi, dan integrasi. Motivasi-motivasi ekstrinsik ini dipengaruhi oleh faktor-faktor yang berbeda yang berasal dari luar diri individu. Individu dapat menunjukkan perilaku yang sama akan tetapi didasari oleh motivasi yang berbeda. Hal ini juga berlaku pada mahasiswa yang mengikuti organisasi mahasiswa. Mahasiswa dapat menunjukkan perilaku yang sama yaitu aktif mengikuti organisasi, akan tetapi di latar belakangi oleh alasan yang berbeda.

Self Determination Theory (SDT) mengajukan konsep bahwa terdapat perbedaan tipe motivasi berdasarkan alasan atau tujuan yang mendasari suatu perilaku. Terdapat beberapa tipe motivasi ekstrinsik, beberapa di antaranya, memang merupakan bentuk sederhana dari motivasi dan beberapa di antaranya aktif, beberapa bentuknya agentik (Ryan \& Decy, 2000a). Beberapa dasar motivasi ekstrinsik diantaranya adalah:

1. Integrasi terjadi ketika peraturan diidentifikasi telah sepenuhnya berasimilasi ke dalam diri sendiri. Hal ini terjadi melalui evaluasi diri dan membawa peraturan baru ke dalam keselarasan dengan nilai-nilai seseorang dan kebutuhan.

2. Identifikasi. Di sini, orang tersebut telah diidentifikasi regulasi dengan perilaku pribadi karena adanya kepentingan dan dengan demikian ia menerima peraturan sebagai bagian dari dirinya 
3. Introyeksi, menjelaskan jenis regulasi internal yang masih mengendalikan seseorang, karena orang melakukan tindakan tersebut dengan perasaan tekanan untuk menghindari rasa bersalah atau kecemasan atau untuk meningkatkan ego atau kebanggaan

4. Regulasi Eksternal. Perilaku tersebut dilakukan untuk memenuhi permintaan eksternal atau mendapatkan hadiah.

Masalah penelitian yang diajukan dalam penelitian ini untuk mengetahui selain gambaran motivasi mahasiswa untuk mengikuti organisasi mahasiswa secara aktif di Universitas Jenderal Achmad Yani. Dasar teori motivasi yang digunakan dalam penelitian ini adalah pendekatan self determination theory oleh Ryan dan Decy (2000a), yang menganggap motivasi sebagai suatu kontinum yang mendasari seseorang berperilaku untuk mendapatkan alasan atau tujuan yang diberikan untuk melakukan suatu tindakan. Kontinum bergerak dari mahasiswa mengikuti kegiatan organisasi mahasiswa untuk mendapatkan sesuatu dari lingkungan (motivasi ekstrinsik) hingga mahasiswa mengikuti kegiatan organisasi mahasiswa karena ketertarikan atau perasaan senang yang dirasakan (motivasi intrinsik).

\section{METODE}

\section{Desain Penelitian}

Penelitian non-eksperimental dan pendekatan yang digunakan dalam penelitian ini adalah pendekatan induktif dengan tujuan mengetahui gambaran dari fenomena yang ada. Diharapkan dengan adanya pendekatan yang berbeda, maka didapatkan gambaran yang lebih menyeluruh terkait motivasi mahasiswa dalam mengikuti kegiatan organisasi mahasiswa di Universitas Achmad Yani. Penelitian ini menggunakan variabel Motivasi Intrinsik atau Motivasi Ekstrinsik sesuai konsep yang dikemukakan oleh Deci dan Ryan dalam Self Determination Theory (Ryan \& Deci, 2000a).

\section{Partisipan Penelitian}

Subjek penelitian ini adalah mahasiswa Unversitas Achmad Yani yang aktif dalam berbagai organisasi kemahasiswaan baik di level universitas maupun di level fakultas yang 
berjumlah 150 orang. Pengambilan sampel yang digunakan adalah non probability sampling dengan teknik snowball sampling.

\section{Instrumen Penelitian}

Instrumen penelitian yang digunakan adalah kuesioner extrinsic intrinsic motivation (Ryan \& Deci, 2000a). Alat ukur ini terdiri dari 22 item yang telah dianalisis item dan reliabilitasnya. Analisis item ditunjukkan dengan adanya korelasi antara item dan skor total (Azwar, 2003). Item yang layak adalah item dengan koefisien korelasi di atas 0.3. Uji reliabilitas menggunakan teknik Alpha Cronbach dengan koefisien reliabilitas sebesar 0.894 yang berarti bahwa alat ukur tersebut reliabel.

\section{Prosedur Pengambilan Data}

Penelitian diolah melalui dua tahap. Pada tahap pertama, peneliti menentukan masing-masing responden berada pada tipe motivasi yang mana beradasarkan teori Ryan dan Decy (2000a). Ini didapatkan dengan mencari rata-rata pada tiap tipe dan menentukan rata-rata terbesar sebagai tipe motivasi yang dimiliki partisipan. Tahap kedua, peneliti menganalisis dinamika pada tiap-tiap tipe motivasi untuk mengetahui gambaran perilaku serta faktor-faktor yang mempengaruhi motivasi partisipan dalam mengikuti organisasi di lingkungan kampus Universitas Achmad Yani.

Selain data utama peneliti juga mengumpulkan data tambahan seperti tahun pertama mengikuti kegiatan organisasi; jabatan yang diampu saat ini; dan semester yang sedang ditempuhnya. Peneliti juga memastikan bahwa data yang didapatkan berasal dari berbagai fakultas yang ada di Universitas Achmad Yani.

\section{HASIL}

Ryan dan Decy (2000a) membagi motivasi menjadi dua yaitu motivasi ekstrinsik dan motivasi intrinsik. Pada motivasi ekstrinsik terbagi menjadi empat tipe yaitu, regulasi eksternal, identifikasi, introyeksi, dan integrasi. Berdasarkan data didapatkan bahwa mayoritas mahasiswa berada pada motivasi ekstrinsik pada tipe integrasi. Tipe motivasi terbanyak kedua adalah tipe motivasi intrinsik kemudian diikuti dengan motivasi 
ekstrinsik dengan tipe identifikasi. Tipe yang paling sedikit adalah motivasi ekstrinsik dengan tipe regulasi eksternal.

Peneliti kemudian melakukan analisa pada masing-masing tipe motivasi dengan mengelompokkan partisipan pada rentang rata-rata yang telah ditentukan. Didapatkan hasil sebagai berikut.

Tabel 1

Frekuensi pada Tiap Tipe Motivasi Mahasiswa

Kegiatan Organisasi Mahasiswa di Universitas Achmad Yani

\begin{tabular}{lccc}
\hline \multirow{2}{*}{ Tipe Motivasi } & \% & Tinggi & Sangat Tinggi \\
\cline { 3 - 4 } & & F & F \\
\hline Regulasi Eksternal & 2 & 3 & \\
\hline Introyeksi & 3 & 3 & 6 \\
\hline Identifikasi & 14 & 15 & 51 \\
\hline Integrasi & 32 & 22 & 21 \\
\hline Motivasi Intrinsik & 49 & 27 & \\
\hline
\end{tabular}

Berdasarkan tabel 1 didapatkan bahwa mahasiswa yang berada pada tipe motivasi ekstrinsik integrasi memiliki frekuensi paling banyak pada kategori sangat tinggi. Motivasi ekstrinsik integrasi melebihi tipe motivasi lain seperti regulasi eksternal, introyeksi, motivasi intrinsik, dan identifikasi.

\section{PEMBAHASAN}

Ketika mahasiswa masuk ke perguruan tinggi, mahasiswa diharapkan mampu mengembangkan diri dari segi akademis maupun non-akademis. Perguruan tinggi merupakan institusi yang memungkinkan mahasiswa untuk mengembangkan keterampilan diri mereka tidak hanya melalui kegiatan akademis tetapi juga dengan mengikuti kegiatan organisasi. Terdapat perbedaan keterampilan antara siswa yang aktif mengikuti organisasi dan tidak (Foubert \& Grainger, 2006). Ditemukan bahwa siswa yang aktif organisasi memiliki korelasi positif dengan beberapa perkembangan psikososial. Copper (1994) dalam (Foubert \& Grainger, 2006) menjelaskan bahwa mahasiswa yang aktif organisasi memiliki skor yang lebih tinggi dalam keterlibatan akademis, 
perencanaan karier, perencanaan gaya hidup dan kemandirian akademis. Terdapat pengaruh keterlibatan mahasiswa pada kegiatan organisasi dan terdapat hubungan antara keterampilan mahasiswa berbicara depan umum, kemampuan kepemimpinan serta keterampilan interpersonal dengan berapa lama waktu yang dihabiskan dalam berpartisipasi pada kegiatan organisasi mahasiswa (Astin, 1993). Sumber utama yang mendorong perkembangan kognitif dan afeksi pada mahasiswa adalah kesempatan berinteraksi dengan teman seperti yang didapatkan di organisasi. Penelitian ini bertujuan mengetahui motivasi mahasiswa untuk mengikuti organisasi mahasiswa secara aktif di Universitas Jenderal Achmad Yani.

Dalam Self-Determination Theory (SDT), Ryan \& Deci (2000a) membedakan tipe motivasi berdasarkan perbedaan alasan atau tujuan yang diberikan untuk melakukan suatu tindakan. Perbedaan yang paling mendasar adalah antara motivasi intrinsik yang mengacu pada pengertian seseorang mengerjakan sesuatu karena ketertarikan yang muncul dalam dirinya, atau karena pada dasarnya dia senangi. Sementara motivasi ekstrinsik, yang mengacu pada seseorang yang melakukan sesuatu karena mengarah pada sesuatu yang akan dia dapatkan (Ryan \& Deci, 2000a). Individu dapat memiliki tingkatan motivasi yang berbeda-beda. Individu juga dapat memiliki orientasi motivasi yang berbeda-beda. Orientasi dari motivasi menjadi dasar dari sikap dan tujuan yang ingin dicapai melalui perilaku (Ryan \& Deci, 2000a).

Walaupun motivasi intrinsik penting, sebagian besar aktivitas manusia tidak termotivasi secara intrinsik (Ryan \& Deci, 2000b). Seiring berjalannya usia kebebasan untuk termotivasi secara intrinsik mulai terbatasi dengan tuntutan dan peran sosial yang diasumsikan sebagai tanggung jawab yang harus dipenuhi. Tipe motivasi ekstrinsik yang memiliki derajat kemandirian paling rendah adalah terregulasi oleh faktor eksternal (externally regulated). Ryan dan Deci (2000a) menjelaskan bahwa individu dengan tipe ini berperilaku untuk memuaskan tuntutan eksternal yang ada atau berusaha mendapatkan penghargaan atau keuntungan. Hasil penelitian menunjukkan terdapat sedikit partisipan mahasiswa yang memiliki tipe motivasi ini. Mereka mengakui mereka mengikuti kegiatan kemahasiswaan demi memenuhi aturan yang ada serta arahan dari pihak institusi. Mereka juga menjelaskan bahwa mereka mengikuti kegiatan organisasi karena ajakan dari orang lain terutama teman-teman mereka. Didapatkan dari data demografi bahwa mahasiswa-mahasiswa ini sebelumnya tidak mengikuti organisasi 
apapun. Saat ini dalam berorganisasi posisi yang diampu adalah sebagai anggota dan belum menjabat pada struktur organisasi.

Tipe kedua dari motivasi ekstrinsik adalah regulasi terintroyeksi (introjected regulation). Introyeksi dideskripsikan sebagai tipe regulasi internal yang masih dikontrol karena individu menampilkan perilaku dengan tujuan untuk menghindari perasaan bersalah atau kecemasan atau berusaha mencapai kebanggan (Ryan \& Deci, 2000a). Terdapat lima mahasiswa yang berada pada tipe motivasi ini. Dua mahasiswa mengakui alasan mengikuti organisasi karena keinginan untuk terlihat sebagai mahasiswa yang aktif dan tidak dianggap kutu buku. Pengakuan dari institusi sebagai mahasiswa yang aktif juga dirasa penting bagi mereka. Tiga mahasiswa lainnya juga mengakui bahwa pengakuan institusi dan anggapan dari lingkungan menjadi alasan mereka mengikuti organisasi. Hal ini sesuai dengan penjelasan Sanli, Bray dan Lee (2013) bahwa alasan individu dengan tipe motivasi untuk berperilaku adalah untuk menghindari ketidakpersetujuan dari lingkungan. Saat mengikuti organisasi, mahasiswa-mahasiswa ini mengaku tidak begitu mengetahui kegiatan yang dilakukan pada organisasi tersebut, namun karena temantemannya mengikuti organisasi maka mereka juga mengikutinya agar tidak merasa berbeda dengan yang lain.

Kemandirian yang meningkat atau determinasi diri membangun motivasi ekstrinsik dengan tipe identifikasi. Pada tipe ini individu mengidentifikasi alasan berperilaku dengan karena adanya kepentingan dan dengan demikian dia menerima peraturan sebagai bagian dari dirinya (Ryan \&Deci, 2000a). Individu berperilaku dengan menyadari pentingnya aktivitas tersebut untuk dirinya. Individu berperilaku untuk mencapai tujuan yang dirasanya penting atau memenuhi nilai yang dirasa diperlukannya. Hasil pengambilan data didapatkan bahwa ada 6 mahasiswa memiliki skor yang tinggi pada tipe motivasi ini. Mahasiswa-mahasiswa ini menjelaskan bahwa mereka mengikuti organisasi untuk melatih diri agar dapat menjadi orang yang lebih bertanggung jawab. Fasilitas yang ditawarkan oleh masing-masing organisasi juga turut menjadi alasan mahasiswa untuk aktif di organisasi tersebut. Akan tetapi mereka belum melihat organisasi yang diikuti sebagai sarana untuk menyalurkan minat mereka. Gambaran perilaku berbeda ditampilkan pada 15 mahasiswa lainnya. Para mahasiswa ini menyetujui bahwa organisasi membantu mereka untuk mengembangkan kepribadian yang diinginkan. Akan tetapi mereka masih menilai bahwa organisasi yang diikuti belum memberikan 
fasilitas yang diharapkan. Hal ini berkaitan dengan sarana dan prasana yang masih dirasa belum memfasilitasi kegiatan organisasi yang diikuti. Sebagian besar mahasiswa ini belum memiliki pengalaman organisasi sebelumnya. Akan tetapi mayoritas dari mereka telah memasuki semester enam perkuliahan sehingga perencanaan karier diindikasikan turut mempengaruhi pengaturan dalam berperilaku.

Bentuk yang paling otonom pada motivasi ekstrinsik adalah regulasi terintegrasi. Integrasi muncul ketika regulasi telah benar-benar diidentifikan pada diri individu. Semakin individu menginternalisasi alasan dari tindakannya dan mengasimilasikannya pada diri akan membuat individu semakin termotivasi (Ryan \&Deci, 2000a). Ketika individu melakukan sesuatu, individu akan meresapi tujuan sehingga secara pribadi berkomitmen untuk mendapatkan kualitas hasil yang diinginkan. Individu memiliki tujuan untuk memuaskan kebutuhan psikologis yang dimiliki. Sebagian besar mahasiswa yang menjadi partisipan memiliki tipe motivasi ekstrinsik integrasi. Mahasiswamahasiswa ini mengakui bahwa mereka mengikuti kegiatan organisasi karena merasa kegiatan ini akan baik untuk dirinya. Mereka juga yakin bahwa kegiatan kemahasiswaan akan memberikan kebaikan untuk dirinya. Namun ada beberapa mahasiswa mengikuti organisasi walaupun hal tersebut adalah bukan kegiatan yang diikutinya sejak dahulu. Sebagian besar mahasiswa telah mengikuti organisasi kemahasiswaan lebih dari dua tahun. Sebagian besar dari mereka juga menjabat pada posisi-posisi tertentu seperti ketua divisi, sekretaris, wakil ketua hingga ketua umum. Hal ini membuat mereka harus aktif di organisasi sesrta memungkinkan mereka untuk mengembangkan keterampilanketerampilan seperti kemampuan kepemimpinan dan keterampilan interpersonal.

Motivasi intrinsik yang mengacu pada pengertian seseorang mengerjakan sesuatu karena ketertarikan yang muncul dalam dirinya, atau karena pada dasarnya dia senangi (Ryan \& Deci, 2000a). Mahasiswa-mahasiswa yang memiliki tipe motivasi intrinsik menilai bahwa kuliah tanpa mengikuti kegiatan organisasi kemahasiswaa tidaklah menarik. Mereka merasa bahagia ketika mengikuti kegiatan organisasi dan menikmati setiap prosesnya. Pada mahasiswa dengan tipe motivasi ini dengan derajat yang lebih rendah menjelaskan bahwa mereka menyenangi kegiatan organisasi yang diikuti. Mereka juga merasa waktu berjalan dengan cepat saat mereka melakukan kegiatan organisasi kemahasiswaan. Akan tetapi mereka tidak menilai bahwa ketika mahasiswa berkuliah itu harus mengikuti kegiatan organisasi. 
Ryan dan Deci (2000b) menjelaskan terdapat perbedaan sikap dan kemampuan menyesuaikan diri pada tipe motivasi yang berbeda. Mahasiswa yang memiliki tipe regulasi eksternal tidak menampilkan ketertarikan atau usaha untuk mengikuti kegiatan organisasi yang diikuti. Hal ini berbeda dengan mahasiswa pada tipe introyeksi yang masih menampilkan usaha namun mengalami kecemasan bila tidak memenuhi tuntutan yang ada di lingkungan. Hal ini membuat mereka enggan untuk mengambil tanggung jawab yang lebih di organisasi. Mahasiswa dengan tipe identifikasi mulai menyesuaikan kegiatan organisasi dengan kebutuhan yang dimiliki sehingga mereka dapat mengidentifikasikan hal positif ketika mengikuti kegiatan organisasi. Hal ini juga ditunjukkan pada mahasiswa dengan tipe integrasi yang sudah mulai mengasosiasikan kegiatan organisasi sebagai suatu yang menyenangkan sehingga mereka lebih menampilkan kemauan untuk berusaha. Pada mahasiswa dengan motivasi intrinsik mengikuti organisasi semata-mata karena mereka menikmati dan merasa memiliki kompetensi pada kegiatan yang diikuti.

Vanderboss (2013) menjelaskan terdapat beberapa faktor yang mempengaruhi siswa untuk mengikuti kegiatan berorganisasi yaitu pengalaman organisasi sebelumnya yang dimiliki; serta waktu yang telah dihabiskan dalam mengikuti organisasi. Pengetahun tentang organisasi yang diikuti juga turut mempengaruhi mahasiswa dalam mengikuti kegiatan organisasi. Hal lain yang berpengaruh adalah kesempatan pertemanan dan keuntungan-kentungan yang didapat ketika mengikuti organisasi. Dari hasil analisis diketahui bahwa jalinan pertemanan menjadi salah satu faktor awal bagi mahasiswa untuk mengikuti kegiatan organisasi. Hal ini terutama pada mahasiswa yang belum memiliki pengalaman organisasi sebelumnya. Pengalaman mengikuti organisasi dan lamanya mengikuti organisasi juga terlihat mempengaruhi motivasi mahasiswa. Hal ini ditunjukkan pada tipe motivasi identifikasi dan integrasi yang telah mengikuti kegiatan organisasi data SMA dan juga telah lebih dari dua tahun mengikuti kegiatan organisasi kemahasiswaan di Unjani.

Faktor lain yang turut mempengaruhi adalah keuntungan yang didapatkan ketika mengikuti organisasi. Mahasiswa-mahasiswa pada tipe identifikasi menilai bahwa kegiatan organisasi membantu mereka menjadi pribadi yang mereka inginkan. Walaupun mereka tidak mengharapkan terkait fasilitas yang diberikan ketika mereka mengikuti 
kegiatan organisasi. Kebutuhan ini yang mengarahkan mereka untuk menampilkan usaha yang maksimal dan berani mengambil tanggung jawab untuk memegang jabatan di organisasi yang diikuti. Hal ini sesuai dengan hasil penelitian Vanderboss (2013) yang menyatakan bahwa mahasiswa mengikuti kegiatan organisasi untuk mengembangkan relasi sosial yang dimiliki serta mengembangkan keterampilan kepemimpinan. Keterampilan dan pengembangan kepribadian menjadi hal yang dituju ketika mengikuti organisasi.

Terdapat beberapa kesimpulan yang dapat diambil pada penelitian ini, yaitu: Sebagian besar mahasiswa mengikuti kegiatan organisasi kemahasiswaan memiliki tipe integrasi. Faktor pertemanan menjadi faktor utama, dan didukung faktor kesadaran akan keuntungan berorganisasi bagi mahasiswa dalam mengikuti organisasi kemahasiswaan. Pihak universitas juga perlu meningkatkan informasi yang dimiliki mahasiswa tentang organisasi yang akan diikuti karena tersebut bisa meningkatkan motivasi dalam mengikuti kegiatan organisasi kemahasiswaan.

\section{DAFTAR PUSTAKA}

Amir Nuyman S, 2010, Pengembangan Program Tahun Pertama Mahasiswa Fakultas Psikologi Unjani. Tesis, Tidak dipublikasikan.

Antony M. Graziano \& Michael L. R. 2000. Research Methods a Prosess of Inquiry 4th edition. Allyn and Bacon.

Astin, A. W. 1993. What Matters in College? Four Critical Years Revisited. San Fransisco: Jossey-Bass.

Foubert, J D \& Lauren U. Grainger. 2006. Effects of Involvement in Clubs and Organizations on the Psychosocial Development of First-Year and Senior College Students. NASPA Journal Vol. 43, no, 1 166-181.

Hasanuddin Noor. 2009. PSIKOMETRI Aplikasi Dalam Penyusunan Instrumen Pengukuran Perilaku. Bandung: UNISBA

Jex, Steve M. 2002. Psychology: A Scientist-Practitioner Approach. New York: John Wiley $\&$ Sons 
Lewin. 1980. Understanding Psychological Research. New York: John Willey \& Sons, Inc.

Ray, L. 2016. Importance of Organization for Students. Diambil dari: http://work.chron. com/importance-organization-students-5588.html

Republik Indonesia, 1998. Keputusan Menteri Pendidikan dan Kebudayaan No. 155/U/1998 Pasal 5 Tahun 1998 tentang Fungsi Organisasi Kemahasiswaan. Lembaran Negara RI Tahun 1998. Sekretariat Negara. Jakarta.

Republik Indonesia, 2003. Undang-Undang No. 20 Tahun 2003 Pasal 4 Ayat 5 tentang Prinsip Pendidikan Indonesia. Lembaran Negara RI Tahun 2003. Sekretariat Negara Jakarta.

Republik Indonesia, 2012. Undang-Undang No. 12 Tahun 2012 Menimbang tentang Pendidikan Tinggi. Lembaran Negara RI Tahun 2012. Sekretariat Negara Jakarta

Republik Indonesia, 2012. Undang-Undang No. 12 Pasal 5a dan 5b tentang Pendidikan Tinggi. Lembaran Negara RI Tahun 2012. Sekretariat Negara Jakarta

Republik Indonesia, 2012. Undang-Undang No.12 Pasal 14 tentang Sivitas Akademika. Lembaran Negara RI Tahun 2012. Sekretariat Negara Jakarta

Republik Indonesia, 2012. Undang-Undang No. 12 Tahun 2012 Pasal 77 tentang Organisasi Kemahasiswaan. Lembaran Negara RI Tahun 2012. Sekretariat Negara Jakarta

Ryan, R. M., \& L.Deci, E. 2000a. Intrinsic and Extrinsic Motivations: Classic Definitions and New Directions. Contemporary Educational Psychology 25, 54-67.

Ryan, R. M., \& L.Deci, E. 2000b. Self-Determinantion Theory and the Facilitation of Intrinsic Motivation, Social Development and Well-Being. American Psychologist Assocation Vol. 55, No. 1, 68-78.

Saifuddin Azwar. 2003. Penyusunan Skala Psikologi. Yogyakarta: Pustaka Pelajar

Sanli EA, Patterson JT, Bray SR and Lee TD. 2013. Understanding self-controlled motor learning protocols through the self-determination theory. Front. Psychology 3:611. doi: 10.3389/fpsyg.2012.00611

Vanderbos, S. 2013. Factors that influence secondary students to join the Collegiate FFA. Dissertation. Utah: Utah State University 